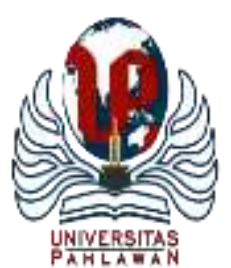

Edukatif : Jurnal Ilmu Pendidikan Volume 4 Nomor 1 Tahun 2022 Halm 1170 - 1181

EDUKATIF: JURNAL ILMU PENDIDIKAN

Research \& Learning in Education

https://edukatif.org/index.php/edukatif/index

\section{Paradigm of Pancasila Economic as The Identity of Indonesia Nation}

\author{
Rizal Al Hamid ${ }^{凶}$ \\ Universitas Islam Negeri Sunan Kalijaga Yogyakarta, Indonesia \\ E-mail : rizalalhamid@uin-suka.ac.id
}

\begin{abstract}
Abstrak
Diantara solusi dalam menghadapi permasalahan negeri ini adalah dengan menumbuhkan kembali semangat Pancasila. Itu adalah sumber dari entitas Indonesia sebagai sebuah Negara. Pancasila juga memiliki fungsi sebagai ideologi, prinsip dan falsafah bangsa, serta sebagai representasi pokok dasar bagi negara yang merdeka. Oleh karena itu, revitalisasi Pancasila harus menjadi tujuan utama dari rangkaian wacana pemerintah, agar nilai-nilai yang terkandung di dalamnya mampu meresapi setiap masyarakat negeri ini. Para Founding Fathers percaya bahwa Pancasila tidak hanya mampu mempersatukan warga negara, tetapi juga untuk membebaskan mereka dari belenggu kesenjangan sosial, kemiskinan, kelaparan, dan praktik korupsi yang merajalela. Dalam tulisan ini, kami uraikan serangkaian wacana tentang ekonomi yang khas di negeri ini, yaitu Ekonomi Pancasila. Hal ini diyakini mampu membebaskan belenggu keterpurukan tersebut, bahkan tanpa merugikan pihak lain, seperti yang terjadi dalam konsep ekonomi kapitalis, sosialis, dan liberal. Temuan tulisan ini adalah bahwa sesungguhnya Ekonomi Pancasila merupakan bagian dari pendekatan ekonomi heterodoks, yang mengandung konsep ekonomi sosialis dan kapitalis. Meskipun demikian, Ekonomi Pancasila tidak berarti mengadopsi kedua konsep ekonomi tersebut, melainkan merupakan bentuk hibrida dan telah dimodifikasi sesuai dengan nilai-nilai yang terkandung dalam sila-sila Pancasila.
\end{abstract}

Kata Kunci: Ekonomi Pancasila, Jati Diri Bangsa, Kesejahteraan Nasional

\begin{abstract}
Among the solutions in dealing with the problems of this country is to regenerate the spirit of Pancasila. It is the source of the Indonesian entity as a State. Pancasila also has a function as an ideology, principles, and philosophy of the nation, as well as a basic principle representation for an independent country. Therefore, the revitalization of Pancasila should be the main objective of a series of government discourses, so that the values contained in it are able to permeate every society of this country. The Founding Fathers believed that Pancasila was not only able to unite the citizen, but also to alleviate them from the shackles of social inequality, poverty, hunger, and rampant corrupt practices. In this paper, we describe a series of discourses about the economy that is unique to this country, namely the Pancasila Economy. It is believed to be able to free the shackles of these downturns, even without harming other parties, as happened in the economic concept of capitalist, socialist, and liberal. The findings of this paper are that in fact, Pancasila Economy is part of the heterodox economic approach, which contains the concept of a socialist and capitalist economy. Even so, Pancasila Economics does not mean adopting the two economic concepts, but rather a hybrid form and has been modified in line with the values contained in the principles of Pancasila.
\end{abstract}

Keywords: Pancasila Economy, National Identity, National Welfare

Copyright (c) 2022 Rizal Al Hamid

$\triangle$ Corresponding author:

Email : : rizalalhamid@uin-suka.ac.id

DOI $\quad$ : https://doi.org/10.31004/edukatif.v4i1.2073

ISSN 2656-8063 (Media Cetak)

ISSN 2656-8071 (Media Online)

Edukatif : Jurnal Ilmu Pendidikan Vol 4 No 1 Tahun 2022

p-ISSN 2656-8063 e-ISSN 2656-8071 


\section{INTRODUCTION}

The discourse around the paradigm of economic thought or economic thought, especially on national economic development and development, has always been a hot topic and never stopped being discussed. It is no longer a secret that Indonesia is currently included in a series of countries in the world that are in the phase of emerging markets or developing markets (Jaelani, 2016) and even occupying the highest level on the global economic stage. However, in recent times, it has become very evident how the foundations and the economic system in this country are experiencing fragility, where when experiencing the global economic crisis in Europe and America, it turns out that this has also penetrated the Asian world, not least. Indonesia is also affected, and in the end, this will certainly reduce economic growth in this archipelago (Salim, 2021).

We may still remember the events at the end of 2012 to early 2013, where the term Fragile Five appeared for five countries that experienced the most fragile economic systems of other economic systems around the world. The five countries are South Africa, Brazil, India, Turkey, and in fifth place in our country, Indonesia. The fragility of the five countries against the exchange rate is caused by capital flight. They also experienced exchange rate depreciation or a sharp depreciation of the exchange rate against the dollar. That means that this country at that time was also one of the most fragile countries due to a sudden and massive foreign capital reversal due to foreign policy. At that time, the weakening of the rupiah even reached Rp11, 613/USD, as of July 2013 (Mubyarto, 2000). This weakening was due to a trade balance deficit. In the end, BI then raised the interest rate to 7.5\%, thus weakening investment realization (Wibisono, 2019).

Other external problems are also internal, were in the same year, inflationary pressure was also very high, which has even become a bitter record for the Indonesian economy in the last decade, reaching a peak of 8.79\% (Jaelani, 2016). In addition, data from the Central Bureau of Statistics or BPS in the same year shows the number, how the number of workers until the eighth month was only 110.80 million people, this decreased from the previous month, which had reached 114.02 million inhabitants (Agusalim, 2014). This situation certainly gives us a clear picture of how the unemployment rate in this country is increasing. In addition, the capability and quality of the skills of the nation's children are also still relatively minimal, so that in the end it continues to spread to the unstoppable poverty rate. In addition to economic problems, Indonesia also still suffers from seemingly endless problems, including the rampant culture of $\mathrm{KKN}$, money laundering, weak legal reform, abuse of illegal drugs, etc.

The above reality is a clear picture that there are things that need to be addressed in the Indonesian economic system. During the last three years, the government has even revised the projection of the economic system for the umpteenth time, which was previously optimistic but later became pessimistic. According to Agusalim, the source of this problem is that, because Indonesia leans towards neoliberalism, the ruler (in this case the government) simply leaves economic affairs to the free market (Agusalim, 2014). This situation seems very real, how this country does not have sovereignty in the issue of globalization, which is due to the ratification of international agreements, which in fact may not be able to resolve the fundamental problems of this country. In addition, government regulations and policies often worsen the country's economic conditions due to stagnant good governance.

According to Subiakto Tjakrawerdaja, currently, Indonesia needs a revitalization of the economic concept called the Pancasila concept, in order to realize the hopes and ideals of the nation's welfare. Gasan Tjakrawerdaja mentioned above is not without reason. He provides the background to the success of the Pancasila economy which was applied in 1966-1996. In that year it has been proven that the concept and economic system of Pancasila has succeeded in reducing the poverty rate, from the beginning of 54.2 million people $(40.1 \%)$, namely in the middle to the end of 1976, then sloping down to 22.5 million people $(11,2011)$. $3 \%$ ) in 1996. That means, there are at least 31.7 million people, who have entered the phase of financial prosperity (Tjakrawerdaja, 2017). 
1172 Paradigm of Pancasila Economic as The Identity of Indonesia Nation-Rizal Al Hamid DOI: https://doi.org/10.31004/edukatif.v4i1.2073

\section{RESEARCH METHODS}

\section{Problems}

This research is based on the problems that still happen now in Indonesia and are faced by the citizens of Indonesia. They are mentioned as below:

1. How is the progress and development of the Pancasila economy in Indonesia?

2. What are the roles of other economic systems in Indonesia's economy?

\section{Research Aims}

This research aims are to know the progress and development of the Pancasila economy and its implementation in Indonesian citizens' economical life, also to analyze the roles of other world's economic systems in regarding their influences on Indonesia's economic systems.

\section{Methods}

This research is qualitative, namely describing or explaining the data obtained using words, not numbers (Lexy J Moleong, 2004). Qualitative research aims to obtain a complete picture of something according to the view of the human being studied. Qualitative research deals with ideas, perceptions, opinions, or beliefs of the people being studied, all of which cannot be measured by numbers (Basuki Sulistiyo, 2010). This type of research emphasizes the process of describing and expressing (to describe and explore), after that it is continued with the process of describing and explaining (to describe and explain) the object under study (Muzairi, et al, 2014).

The research that will be used is a type of research library, namely a study of various kinds of literature related to the title of the study. The literature used is not only in the form of books but other reading sources from various media such as articles and journals, youtube, online media, etc. The study is carried out reflectively and carefully in order to reach the deepest meaning of each text presented.

This research is a type of library research. What is called library research or often also called literature study, is a series of activities related to methods of collecting library data, reading and taking notes, and processing research materials (Mestika Zed. 2008). Meanwhile, Mahmud in his book Educational Research Methods explains that library research is a type of research conducted by reading books or magazines and other data sources to collect data from various pieces of literature, both libraries and in other places (Mahmud. 2011). From the explanation above, it can be understood that library research is not only an activity of reading and recording the data that has been collected. But more than that, researchers must be able to process the data that has been collected with the stages of library research.

In this study, the author applies the library research method because at least there are several underlying reasons. First, data sources cannot only be obtained from the field. Sometimes data sources can only be obtained from libraries or other documents in written form, either from journals, books, or other literature. Second, a literature study is needed as a way to understand new symptoms that occur that cannot be understood, then with this literature review, it will be possible to understand these symptoms. So that in overcoming a symptom that occurs, the author can formulate a concept to solve a problem that arises. The third reason is that library data remains reliable to answer the research questions. However, information or empirical data that has been collected by other people, whether in the form of books, scientific reports, or research reports, can still be used by library researchers. Even in certain cases, the field data is still not significant enough to answer the research questions to be carried out.

Sources of data that have been collected through the literature research above, were analyzed and processed using several research methods, namely the method of description, interpretation, and reflection. a. Descriptive Method; aims to describe this research or describe a thought clearly and thoroughly. This method seeks to describe a concept of thought in more detail. b. Hermeneutic Approach; The word "hermeneutic" comes from the Greek "hermeneuein" which means to interpret, the noun "hermeneia", literally can be interpreted as "interpretation" or interpretation, while in interpreting it is called "hermeneut" (Sudarto, 1997). Hermeneutics itself can be divided into three categories, namely: philosophy, criticism, and theory. However, 
in its development hermeneutics as a method of interpretation was developed by several thinkers, giving rise to various kinds of hermeneutics in accordance with the understanding of each thinker.

\section{LITERATURE REVIEWS}

According to the article written by Vedi R. Hadiz and Richard Robinzon titled The Political Economy of Oligarchy and The Reorganization of Power in Indonesia, described how the political domination during the Soeharto (the second president of The Republic of Indonesia) that lasted for three decades has influenced the economic system that resulted in economical domination as well. Even after the fall of Soeharto regimes, the control of public offices and state authority still existed.

While an article with the title of Revitalization of Pancasila Economic System in the Globalization Era by Waspodo Tjipto Subroto said that the socialization of Pancasila economy to pursue and drive Indonesia's economic system into Pancasila Economic by implementing the value of Pancasila itself into economic policies. It has to be done to slow the bad impact and the influences of Globalization economic into Indonesia's economics.

In this article, the writer gives stressing on the lower economic people's empowerment, the recognition of property possession, and rights. The social values are positioned at the highest level rather than individuals. The western or eastern economic systems don't matter regarding their roles in influencing Indonesia's economic system as long as it's suitable with the values of every point of Pancasila.

\section{RESULT AND DISCUSSION}

\section{Principles of the Pancasila Economic Concept}

Michael Todaro said that the accelerated economic growth path was not followed by the growth of improvised financial distribution for the entire population, (Todaro, 2003) because of the rapid economic growth. It could adversely affect the middle class that, they would be marginalized and eroded by structural changes or structural changes to modern economic growth.

According to Eric Assadourian in his book The Path to Degrowth in Overdeveloped Countries, the increasing achievement of economic growth has resulted in a decline in the quality of life of individuals, humanitarian disasters, and environmental crises. He even suggested the need for a revision of the economic system by way of growth for the sake of upholding welfare. This certainly makes it imperative without having high and high economic growth and consumption ambitions. (Assadourian, 2012)

In this case, Jean Baudrillard sharply criticized the ideology of growth or the ideology of growth. $\mathrm{He}$ revealed how the ideology of growth will only give birth to two possibilities as well as facts on the ground, namely poverty, and prosperity. (Baudrillard, La société de consummation, 2011) Poor is for those who are marginalized and prosperous for those who benefit. According to him, the ideology of growth only dominates the function of poverty. It (the ideology of growth) also only leads to psychological impoverishment or psychological impoverishment efforts, and systemic poverty or systemic poverty, because a need often exceeds the production limit. The act of consuming that exceeds a production limit is a form of greed and greed.

Baudrillard even expresses his criticism on one of his works, Why Hasn't Everything Already Disappeared? (Why Everything Hasn't Disappeared), that in essence, no individual is always sufficient, all individuals, according to him, are trying to combine structural excesses with structural poverty. (Baudrillard, Why Hasn't Everything Already Disappeared? 2009) Individuals essentially live in a growing environment. However, this growth does not bring the individual closer to an affluent society and environment. As if growth is capable of producing growth and prosperity, but in reality, growth is a function of poverty. Growth is also actually present in order to limit the mobility of the poor and marginalized, as well as those who actually maintain an already lasting system. The growth of society according to Baudrillard is in fact only a form of opposition from a self-sufficient society. This ongoing counter reality ultimately has an impact on 
psychological impoverishment and systemic poverty, because the need periodically will always exceed the production limit of goods. (Baudrillard, La société de consommation, 2011)

Strictly speaking, Richard Heinberg states that three substantive factors can end the growth of a nation's economic system, namely: the decline in the availability of key resources (including mineral resources and fossil energy), second, the occurrence of environmental degradation or deterioration as a result of resource extraction or resource extraction, and resource utilization, and third is the financial confusion caused by the inadequacy of the monetary system, investment, and banking, in the context of financing and recovering resources, as well as fixing environmental damage caused by economic growth. (Heinberg, 2011)

In 2008, Nicholas Sarkozy, who was still the first person in France, tested the validity and capability of the economic growth model. At that time, he eventually formed a Commission on the Measurement of Economic Performance and Social Progress (CMEPSP). The commission was headed by Joseph Eugene Stiglitz, the commission's advisor was Amartya Sen, and the commission's coordinator was Jean Paul Fitoussi. This commission aims to amend various levels of economic performance which it deems no longer adequate, in particular to the level of measurement of gross domestic product (GDP) or Gross Domestic Product (GDP).

This Commission eventually gave birth to the preparation of a report by the Commission on the Measurement of Economic Performance and Social Progress (Fitoussi, 2009) or a Commission Report on the Measurement of Economic Performance and Social Progress. The report has even been translated into Indonesian, in which it contains three basic recommendations, namely; first, Gross Domestic Product, which includes government output measures or measures of government output, adjustments or adjustments in the framework of an open economy, treatment of household production, and defensive spending, namely things needed to stabilize the status quo, such as defense and security, etc.) Second, it is the quality of life or quality of life and prosperous life. And the third is sustainable environment and development. (Umam, 2017)

The results of the CMEPSP also convey the urgency of calculating welfare that prioritizes the principle of household or family, equality or equity, as well as expanding the measurement of non-economic activities. In the contents of the report, the commission also clearly revised the issue of the dimensions and paradigm of welfare which until now has often been used to assess the progress of a country's economic condition. (Fitoussi, 2009) Empirically, this commission concludes that the level of welfare measurement is very closely related to various dimensions or multidimensional, which of course needs to be reviewed and considered in measuring the level of welfare, among which are first, the material standard of living or material standard of living, which includes consumption, income and wealth, second, healthy or health, third, education or education, fourth, individual activity or individual activities including work and social activities, fifth, political vote or voting politics includes governance, sixth, interpersonal relationships or interpersonal relationships, seventh, living environment or the environment, including in reaching present and future conditions, and eighth is insecurity or insecurity, both economic and physical.

The various concepts and theories, as well as the critique of the reality that we have described above, then arose the idea of regenerating an alternative economy that seemed to have been buried for a long time by the reform order. The concept of an alternative economy is substantively divided into two groups, first, those who are pro-economic growth. This group also includes attributes that smell like a green and blue economy, a form and economic system to optimize the welfare of individuals and the people, as well as minimize environmental adverse impacts, and optimize marine resources. And the second groups are those who are in opposition and even sue and do not want their dependence on the system of economic growth.

The pattern of the last group above is then further divided into two, namely, first, those who are intense on the issue of economic growth, which consists of the Steady State Economy or the economy in steady conditions, the Growth or growth, and the Post Growth Society or post-community growth. And the second is those who are intense on human welfare, which consists of four things, namely Buen Vivir (a term for rights to the universe) which developed in Ecuador and Bolivia, Common Welfare Economy, or general welfare economy. The Solidarity Economy or the economy of solidarity, and finally the Transition Movement. 


\section{Paradigm of Pancasila Economic as The Identity of Indonesia Nation - Rizal Al Hamid}

DOI: https://doi.org/10.31004/edukatif.v4i1.2073

All the ideas and progress of the alternative economy mentioned above, according to Jared A. Goldstein, are included in the heterodox economic approach, which is an economic, development, and political approach, which is a fragment or splinter from the notions and approaches of socialism and capitalism. (Goldstein, 2009)

Based on this conception, the substance of the principles of the Pancasila Economy concept is a new type of alternative economic thought, as well as a splinter from the socialist and capitalist economic concepts. The concept is primordially essentially outside of the second alternative concept, where it can be said that the Pancasila economic concept is a third concept called the Hybrid Economy concept or a combination of previous economic concepts, namely from two large groups of alternative economy. Like the nature of the values that exist in Pancasila, it does not reject the understanding and concept of economic growth and even provides added value by always prioritizing the principles of social justice.

According to Didin S. Damanhuri, the concept map and heterodox system of thought as we have written above are a form that is close to the Pancasila economic system, where these indications appear, seen from the pattern of development of the welfare state which has the following characteristics, namely, first, the concept and system of taxation is quite progressive, which is in line with the concept of social security, where this has effectiveness in protecting the layers of society, especially those occupying the lower strata. Second, it is private figures who act as agents of economic growth or agents of economic growth. This has become a fullfledged market mechanism, where it is tasked with delivering networks that provide direction in the context of decision-making or making decisions for the private sector, without intervention and long-winded bureaucracy. And third, the power of trade union politics or labor union politics as a determinant, (Damanhuri, 2010) where directly, it runs in harmony with parliamentary democracy, as well as the governing parties, as well as those who are in the opposition, so that in the process, this has guaranteed by checking and balancing, as an effort to realize and optimize legal certainty and political rights for each State and party mandate.

As a result, it is evident that Pancasila Economy has a theoretical base of strength, which is a variant of the concept of heterodox economic thought or heterodox economic thought, in which it places more emphasis on socio-democratic patterns, where it is combined with local values of Nusantara culture, namely kinship, and cooperation, in Islam itself this is called ta'awun ala al-birr wa al-taqwa. (Al-Hamid, 2019) Also similar to the pattern of the Solidarity Economy or solidarity economy, whose objectives are; first, contributing to the sustainability of human life, second, being productive independently which is managed collectively, third, running cooperatively, including when facing internal and external problems, and fourth, inter-social/organ relations in line with their respective affiliations, such as MSMEs, Cooperative, etc.

The pattern above has become a strong ambition for the founders of this country with Moh. Hatta, as the central figure. Among the economic progress that has ambition and socio-democratic spirits are contained in articles 33, 34, and 37. (Pratama, 2017) (Al-hamid, 2020) these three articles contain the principles of kinship and cooperation, the dominant role of the State in order to prosper the people, create jobs, live prosperously, as well as the government's responsibility to neglected children and the poor. The idea of the father of cooperatives that can be felt until now is the idea of "cooperatives", an economic and social form that can overcome all economic needs of the nation's children.

\section{Pancasila Economic Characteristics}

According to Mubyarto, the Pancasila economy is an economic system that represents the ideology of Pancasila, namely an economic system in the form of joint ventures or joint efforts on the principle of cooperation and kinship. He also said that the aims, objectives, and applications of the principles of "gotong royong" and kindship were national-holistic, not only limited to the scope of the village, or rural areas. (Mubyarto, Pancasila Economy: Ideas and Possibilities, 1987)

The thing that then becomes a big question for the Indonesian people is what is Pancasila Economy? Is it true that it exists in the real world, or is it just a utopia? To straighten out the views of some Indonesians who still think that the Pancasila Economy is still only a theory on paper, or a picture that is impossible to 


\section{Paradigm of Pancasila Economic as The Identity of Indonesia Nation - Rizal Al Hamid DOI: https://doi.org/10.31004/edukatif.v4i1.2073}

visualize and realize in the real world, this kind of argument has been emphatically dismissed by Mubyarto, he said, that this assumption is caused by The Pancasila economic system, which has been illustrated so far, is in stark contrast to the reality of the economic system that is run every day by the Indonesian people. Furthermore, what has been faced and implemented by the Indonesian people is an economic system that is far from the principles of cooperation and kinship. (Mubyarto, Pancasila Economy: Ideas and Possibilities, 1987).

Mubyarto also expressed five identities and characteristics possessed by the Pancasila economic system, namely; first, cooperatives are the main figure as well as the direction of the economic system. It is said to be one of the real manifestations of collective effort. Article 33 of the 1945 Constitution is the legal basis for this matter, namely that the economic system is structured as a form of collective effort on the principle of kinship, specifically Moh. Hatta said that the principle of kinship, in this case, is cooperatives. From the 1980s, the government's commitment to the advancement of cooperatives has increasingly shown a bright spot. This can be seen from the formation of the Junior Minister for Cooperative Affairs.

Second, the Pancasila Economy is driven by the encouragement of an economic system that focuses on social and moral values. It is the answer to the reality on the ground of the degradation of society's values and morals. One of the clear evidence is the increasing frequency of business behavior that overrides norms, ethics, and religiosity. This situation is due to the increasingly widespread understanding of monopolism, individualism, and liberalism which is increasingly far from the knowledge of the socio-moral dimension of the economic system. The Pancasila economy seeks to restore the economic identity, which also contains moral knowledge, and even upholds the principles of economic moral revolution, which in the end, this country's economic steps move by racing an economic system based on socio-moral values.

Third, it is the Pancasila Economy highly upholds the egalitarian principle, namely the determination and will of the Indonesian people towards the path of social equity. We certainly know that the principle of a Capitalist Economy is to seek as much as possible in a market economy, with private hands moving. As for the Pancasila Economy, this is not the case, because basically, it does not have the ambition to monopolize, seek to subjectively seek, manipulate all means, and even harm other parties. The Pancasila economy leads to the spirit of solidarity and kinship. With this spirit, the line between the poor and the rich is not as wide as it is in a capitalist economy.

Fourth, the Pancasila Economy is closely related to the third principle, namely the Unity of Indonesia. The mainstreaming of the Pancasila economic regulation is to create a strong national economic system that animates all of Indonesia's economic wisdom. This is, of course, very much different from a capitalist economy whose scope is international, which as far as possible destroys the search for markets without looking at certain regional boundaries. This is what MNCs or Multi-National Corporations do, where regional or country boundaries are not a problem for them, as long as the goal can be achieved, which is to get the greatest possible profit. In Pancasila Economy, it only provides national legitimacy or legitimacy on a national scale.

And lastly, the Pancasila economic system commits in terms of balancing between central/national planning, with pressure on decentralization in the implementation of economic activities. Or in another sense, there is a concrete balance between the existing planning at the national level and the decentralization of various central/national plans in each region.

Some academics, especially economists, may agree that the five characteristics of the Pancasila Economy as stated by Mubyarto in his book, are still limited to ideas, ideas, hypotheses, and are still theoretical. But again, if not attempted, it is only a utopia and fantasy imagination of theorists.

Boediono revealed about Pancasila Economy in his book, "Indonesian Economy, Where are you going?", that Pancasila Economy has five characteristics, namely: first, the presence of a dominant real figure in the form of "cooperatives" in economic life. In the form of business (macro) that cannot be managed optimally and efficiently (such as cooperatives), state-owned companies are in control. As for the form of business that cannot be managed optimally and efficiently by both, in principle and practice, private 
companies take over the roles of both. However, all types and forms of business in the Pancasila economic system are required to be based on a family harmony system, and not on the principle of individual interests as well as certain conflicts of interest.

Second, it is the implementation of a moral-economic booster in an effort to mobilize the wheels of the economy, this is based on the view that humans are actually not limited to economic men or humans who always think materialistically for the sake of economic value, but humans are also actually social and religious men, or always have social and religious instincts. The second human nature can be developed in harmony with the previous nature, in the context of worldly activities (economics) that are still alive in the world. So that in this case, the urge to optimize individual needs and interests (opportunism) is no longer the dominant motive for the rotation of the economy.

Third, there is social dominance and inclination towards egalitarian or social equity. This principle is similar to what has been written by Mubyarto in his book that the Pancasila Economy is in the form of separating, or minimizing the dichotomy between the rich and the poor, so that in it there is no longer any inequality, both in terms of social and economic terms.

Fifth, it is the effort to rely on a decentralized system for the application of economic activities, accompanied by strong planning as a guide for economic development. This is reflected in the real ideals of cooperatives, where it becomes a crystallization of hope to achieve a balance between decentralization and centralism in making joint decisions. (Boediono, 2010)

As for the level of the Act, it can be seen in the Law on cooperatives no. 12/67, Law on the principle of welfare no. 6/74, Law on Child Welfare No. 4/79, Law on community-based environmental governance no. 4/28, Law on communication and prosperity no. 3/89, Law on shipping to the public no. 21/92, Law on Prosperous Family No. 10/92, Law on the development of Cooperatives no. 25/92, Law on the economy and banking no. 7/92, Law on MSMEs No. 9/95, Law on food security no. 7/96, Law on State-Owned Enterprises No. 19/2003, Law on the construction of public facilities as the responsibility of the State no. 38/2004, Law on fisheries no. 31/2004, Law on plantations no. 18/2004, Law on State-owned water resources for the people no. $7 / 2004$, etc.

\section{Moral Elements in Pancasila Economy}

Pancasila, which has imbued the Indonesian people, contains elements of values, morals, the spirit of unity, and the Pancasila Economic system. Therefore, the moral of Pancasila Economy is interpreted as a barometer of norms that manage the thinking and acting styles of economic activists towards the sustainability of the Economic concept being carried out. Mubyarto atomistically describes the concept of an economy based on Pancasila with; First, the establishment of the principle of kinship, namely cooperatives. Second, it is Pancasila Economy mainstream socio-moral stimulation. If the classical economic model prioritizes the economic system in order to move the economy itself, in Pancasila Economy, it accommodates the sociomoral dimension. In strengthening these two dimensions, the religious point of view becomes an inseparable central part, because the religious element is the main source of moral values and functions to maintain. Therefore, it must always be united in every consumer and producer. And third, the principle of Nationalism must be the spirit for every economic actor. A sense of nationalism must remain in every type of business, including state-owned enterprises, as well as officials who are directly involved in the company (Mubyarto, Pancasila Economy: Ideas and Possibilities, 1987).

\section{Description of the Pancasila Economic Pattern}

As a national identity, Pancasila can be integrated between one precept and another. or in another sense, that the five are inherent even in the scope and nature of the Economic system. In it there are five characteristics, namely; first, the economic wheel is managed by socio-moral impulses and, the economy itself. Second, it is the strong determination of every people towards an egalitarian system, based on the principle of humanity. Third, the mainstream of economic regulation is to create a strong national economy, 
namely nationalism that animates every economic regulation. Fourth, cooperatives are the guiding figure of the economy and a concrete form of collective effort. And fifth, it is a real and ideal balancing system, between planning at the decentralized and national level in the application of economic activities to ensure socio-economic justice.

The stimulus for an economic activity referred to above is the motive for economic activity introduced by a system of thought and values that illustrates the basic norms upheld in the economic system. Values and norms, such as self-control, tolerance, cooperation, and the spirit of kinship, become the basis for running the economic system pursuing margin only applies to the scope of that side value only. In a sense, individuals should not be used as an instrument in reaping economic profits. All forms of economic activity must always uphold the principles and values of humanity.

While the egalitarian referred to in the second point is social equality, which prioritizes the fulfillment of the spirit of kinship, mutual love for each other, and high solidarity. This is a representation and reflection of the Precepts of "Just and Civilized Humanity". Based on the history and journey of this country, the bond will be strong if there is an atmosphere and conditions that are at the same level, especially when you are in a low position. Far from that, solidarity will be eroded even more when people live in abundance.

The spirit of nationalism, especially in terms of economics and politics, was very visible when fighting against the Japanese and Dutch colonialists at that time. The spirit of nationalism is united in every people without exception. Unfortunately, the spirit of nationalism has been degraded because of the many policies that favor foreigners over the people, such as the existence of a law that was allegedly ordered by foreigners in the 80s. (Tryanti, 2019) We should not wait until we suffer because of policies that are more pro-foreign. The people must rise against the occupation that hides behind slogans for the welfare of the people.

The basic thought of Article 33 of the 1945 Constitution came from Moh. Hatta, the first vice president of the Republic of Indonesia. Regarding the article, he emphasized that "Long-term economic politics includes all efforts and plans to gradually organize the Indonesian economy based on cooperatives. The realization of short-term economic-political outcomes is based on tangible evidence. Even if their nature is different from our ideal for the future, if the results are real to improve the condition of the people and solve the current shortage of prosperity, these actions must temporarily be carried out and carried out by those who can carry them out. (Bawazier, 2017) According to Mubyarto, Hatta separates the definition of economic goals from economic politics. The Indonesian economic system is cooperatives. According to Mubyarto, the system had not been implemented until the 80s. Previously, in 1977, Hatta explained about the concept of the Indonesian economy, that in the last period, Indonesia was still based on the 1945 Constitution and Pancasila, but the State and its economic politics were still under its technocratic doctrine, and often deviated from the intended principles. Even today, liberal politics is still often used as a reference (Mubyarto, Economic Analysis without Vision, 2000).

\section{The Real Form of Pancasila Economy}

After carefully examining the article above on the Pancasila Economy, it can be concluded that the form of business that falls into the category of implementing the Pancasila Economy is first, cooperatives. (Agusalim, 2014) Etymologically, cooperatives are taken according to the Latin word coopere. In English itself, co means collectively or together, while operation means action to do something so that cooperation can be interpreted as an effort to do something collectively or cooperatively. In this regard, collective efforts to do something are carried out by people who have similar concerns and visions. In this case, Enriquez gives the term to help one another or help one another.

Regarding the relevance of virtues and strengths and cooperatives, until now President SBY has said four things, namely. First, economic growth is not limited to being determined by the private sector and BUMN/BUMD, but also by the actions of cooperatives and SMEs. Second, this nation must not forget about the factors why our economic system was able to recover and bounce back from the ' 98 crisis, namely because there are seat belts which are none other than cooperatives and SMEs. Third, from the research and 
application in the field in various countries, an effective step in minimizing unemployment and poverty is by developing cooperatives and MSMEs. Unemployment and poverty rates will fall rapidly if the people's economy, especially cooperatives and MSMEs, is always driven. And fourth, matters that can raise the standard of living of 240 million (productive age) people across the country, namely the people-based economy or cooperatives as well as MSMEs. (Sulistiowati, 2016)

Based on the functionality and benefits of the role of cooperatives, the benefits are divided into two, namely the benefits of cooperatives in terms of the economy and social. (Tahir, 2015) In terms of the economy, it includes an increase in active income, goods and services products will be more economical, growing drives for business based on humanity, and educating the public in optimizing their income effectively and efficiently.

As for social, cooperative benefits include; the creation of a peaceful and peaceful people's life, the creation of human regulations, in the sense that regulations are not built on material principles, but based on a sense of cooperation and kinship, reducing members to have a cooperative spirit and a family spirit.

Second, Private Owned Enterprises. In terms of quantity, the MSME sector has and is currently dominating the Indonesian economic system. However, the contribution to GNP is still quite low compared to macro businesses which are known to be more vulnerable to global economic drama. (Subroto, 2015) To lay a solid economic foundation, one of the strategies that should be pursued is to provide education and guidance to MSME actors.

And third, it is State-Owned Enterprises. The real form of Pancasila economy apart from the two above is State-Owned Enterprises. It has the main task of serving and protecting the public good. Therefore, practically and practically, various kinds of inequality often occur because many excuses are found in the name of the public interest.

\section{CONCLUSION}

The Indonesian people have long coveted the presence of the Pancasila Economic system, more than that, the policy owners also want to get encouragement from experts in their formulation efforts. If the people desire, theoretically, a positive step has been exceeded, and that shows that there is already a need in it. In addition, all individuals, especially stakeholders, must be prepared to sacrifice individual affairs for the greater good, namely the people as a whole. Like lest there be a tendency to understand monopolism and estatism as a tool of free competition that kills the lower economy. The interests and property rights of individuals are indeed guaranteed and recognized, but if it shows a detrimental tendency, then it must be limited, to provide a higher platform for the benefit of the people. In this regard, social values are positioned at the highest level rather than individual barometers.

The Pancasila economy still really needs the contributions of experts who are consistent in exploring the characteristics of original Indonesia, one of which is through various kinds of research and then implementation. Theoretically-referentially, whether it's an eastern or western economic concept, can facilitate the excavation effort, but the determining factor is not both, but a deep knowledge of the characteristics of Indonesian society which is reflected in the values of Pancasila. Academics, especially economists, are certainly aware that efforts in exploring the Pancasila Economic theory cannot run smoothly if it is not based on the principle of belief between knowledge about economics and knowledge in social science disciplines, such as sociology, anthropology, politics, history, to psychology. This trans-disciplinary approach should be grounded by every expert to explore and find the theory to obtain tangible results.

\section{REFERENCES}

Agusalim, L. (2014). Rekonstruksi Ekonomi Pancasila sebagai Perwujudan Keberlanjutan Pembangunan Nasional. Journal of Social Welfare, 1(1), 39-51. 
1180 Paradigm of Pancasila Economic as The Identity of Indonesia Nation - Rizal Al Hamid DOI: https://doi.org/10.31004/edukatif.v4i1.2073

Al-Hamid, R. (2019). Moral Politik Gerakan Mahasiswa dalam Perspektif Tinjauan Filosofis Hukum Islam. Al-'Adalah: Jurnal Syariah dan Hukum Islam, 4(2), 177-193.

Al-hamid, R. (2020). Pancasila dan Kewarganegaraan. Yogyakarta: Kurnia kalam Semesta.

Assadourian, E. (2012). The Path to Degrowth in Overdeveloped Countries. Amsterdam: World Watch Press.

Baudrillard, J. (2009). Why Hasn't Everything Already Disappeared? Columbia: Seagul Books.

Baudrillard, J. (2011). La société de consommation. Columbia: Idea Press.

Bawazier, F. (2017). Sistem Ekonomi Pancasila (Memaknai Pasal 33 UUD 1945). Jurnal Keamanan Nasional, 3(2), 233-252.

Boediono. (2010). Ekonomi Indonesia, Mau ke Mana? Jakarta: Gramedia Pustaka Utama.

Damanhuri, D. S. (2010). Ekonomi Politik dan Pembangunan: Teori, Kritik, dan Solusi bagi Indonesia dan Negara Sedang Berkembang. Bogor: IPB Press.

[Fitoussi, J. P. (2009). Report by the Commision on the Measurement of Economic Performance and Social Progress . Commision on the Measurement of Economic Performance and Social Progress (pp. 1-293) Prancis: Research Gate.

Goldstein, J. A. (2009). Heterodox Macroeconomics: Keynes, Marx, And Globalization. New York: Routledge.

Heinberg, R. (2011). The End of Growth: Adapting to Our New Economic Reality. Canada: New Society Publishers.

Jaelani, A. (2016). Pancasila Economic and The Challenges of Globalization and Free Market In Indonesia. Journal of Economic and Social Thought, 3(2), 241-251.

Limbong, B. (2000). Politik Pertahanan. Jakarta: Media Pustaka.

Moleong, Lexy J. (2004). Metode Penelitian Kualitatif. Bandung: Rosdakarya.

Mubyarto. (1987). Ekonomi Pancasila: Gagasan dan kemungkinan. Jakarta: Pustaka LP3ES.

[Mubyarto. (2000). Economic Analysis Without Vision. Jurnal Ekonomi dan Bisnis Indonesia, 15(4), $397-$ 403.

Muzairi, dkk. (2014). Metodologi Penelitian Filsafat. Yogyakarta: FA Press.

Pratama, A. R. (2017). Sistem Eonomi Indonesia dalam Perspektif Pancasila dalam UUD NRI Tahun 1945. Jurnal Universitas Katolik Parahyangan, 4(2), 304-332.

Salim, A. (2021). Pancasila Economic Character Literacy Program for High School Students. International Journal of Instruction, 14(1), 235-252.

Subroto, W. T. (2015). Revitalization of Pancasila Economic System in the Globalization Era. International Journal of Economics and Financial Issue, 5(4), 860-867.

Sulistiowati. (2016). The Values of Pancasila In Bussines Activites In Indonesia. Jurnal Mumbar Hukum, 28(1), 107-122.

Tahir, M. I. (2015). The Implementation of Pancasila Economic System in Economic Learning At Faculty of Economics State University of Makassar. Journal of Economics and Finance, 6(6), 66-69.

Tjakrawerdaja, S. (2017). Sistem Ekonomi Pancasila. Jakarta: Raja Grafindo.

Todaro, M. (2003). Pembangunan Ekonomi di Dunia Ketiga. Jakarta: Erlangga.

Tryanti, N. (2019). Reactualization of Pancasila Values on Law Establishment in the Economic Globalization Era. Jurnal Pembaharuan Hukum, 6(2), 214-225.

Umam, S. (2017). Ekonomi Pancasila di Tengah Arus Kapitalisme Pasar. Jurnal IAI Tribakti, 28(2), 434-459.

Wibisono, M. G. (2019). Indonesia's Economic Development Policy as Implementation of Pancasila the 
1181 Paradigm of Pancasila Economic as The Identity of Indonesia Nation - Rizal Al Hamid DOI: https://doi.org/10.31004/edukatif.v4i1.2073

Identity of Indonesia. Internation Conference of Economic (pp. 1-12). Surabaya: Unair. 